\title{
Research on Exploration and Practice of Student-oriented Teaching Model of Pharmacology Experiment in Higher Vocational Colleges
}

\author{
Xiurong Wu ${ }^{1, ~ a}$, Hongna Gao ${ }^{1, b}$, Jinxia Li ${ }^{2, c}$, Shuang Wang, d, Weixia Zhang ${ }^{1, \mathrm{e}}$ \\ ${ }^{1}$ Binzhou Polytechnic, Shandong Binzhou, 256603, China \\ ${ }^{2}$ Binzhou Medical University Hospital, Shandong Binzhou, 256600, China

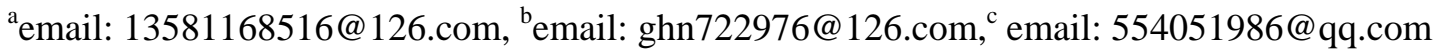 \\ demail:lefuqiushuang@126.com, ${ }^{\mathrm{e}}$ email: bzzhwx@163.com
}

Keywords: student-oriented; pharmacology experiment in higher vocational colleges; teaching model; research on practice

\begin{abstract}
Pharmacology is a subject focusing on practicalness and applicability, also a compulsory course for students in higher vocational medical colleges. In learning pharmacology, pharmacology experiment is also an important part, which enables students to participate in practice, examine the learning of pharmacology knowledge, find out and solve problems in experiment operation. However, there are certain problems in traditional teaching model of pharmacology experiment in higher vocational colleges ${ }^{[1]}$. Based on student-oriented concept, this paper explores problems existing in pharmacology experiment, and puts forward reasonable measures to cultivate the comprehensive practical ability of students.
\end{abstract}

\section{Introduction}

The development of quality-oriented education puts forward new requirement for the practical ability of students that students of pharmacology shall grasp theoretical knowledge, and master certain operational ability and ability of exploration to learn in-depth in pharmacology experiment. Obviously, traditional teaching that students copy and imitate teachers according to theoretical knowledge cannot satisfy this requirement ${ }^{[2]}$. Student-oriented concept, based on the practical ability and ability of exploration, explores new paths to develop teaching model of pharmacology experiment in higher vocational colleges.

\section{Problems in Teaching Model of Pharmacology Experiment in Higher Vocational Colleges}

\subsection{The examination method emphasizing theory of pharmacology}

Traditional examination method of pharmacology course is mainly on theory, involving experiment, but not as reference grade. And involved content of experiment is mostly teaching materials or courseware. Students are not required to operate in laboratory, but pass examinations by memorizing experimental procedures and conclusions in teaching materials, which causes the insufficient attention on pharmacology experiment from teachers and students, even the attitude of ignoring. In this way, pharmacology experiment may lose the significance of its existence easily, failing to meet the goal of cultivating students' operational ability.

\subsection{The self-learning ability of students to be improved}

There is certain drawback in traditional teaching model of pharmacology experiment, which limits the self-learning ability of students. Before traditional pharmacology experiment, the main task of teachers was to teach experimental principle, objective and procedures ${ }^{[3]}$. Students did not need to preview before experiment, and they can complete the entire experiment project according to procedures. Thus, in this model, students easily depend on the teaching and teaching material, not to find out problems in their operation, but to adopt the most direct way to finish experiment. The 
constraint of self-learning ability of students leads to their passive position in pharmacology, where it is difficult for them to mobilize the enthusiasm of learning, which is not conductive to the development of independent thinking and the in-depth learning and exploration of pharmacology experiment.

\section{New Requirement from Student-oriented Teaching Model of Pharmacology Experiment in Higher Vocational Colleges}

\subsection{To cultivate students' ability of observation and analysis}

The operational ability of most students in pharmacology major is weak, so teachers shall provide more opportunities for students to operate, so as to train their ability of observation and analysis. Pharmacology experiment is not simply following experimental procedures and implementing experiment, but students are required to record and analyze according to experimental phenomena in experiment, which can train their ability of thinking. For instance, in the experiment of "Influence of efferent nerve medicine on pupil", some drug effect can be shown in figure, such as human body temperature and the size of pupil, and some can be shown in Yin and Yang, like the reflection of light. For any kind of experimental phenomenon, teachers shall encourage students to record and analyze carefully, which is beneficial for the cultivation of rigorous learning, and the student-oriented characteristics and pursuit in pharmacology experiment.

\subsection{To focus on the cultivation of students' comprehensive competence}

In order to develop student-oriented teaching model of pharmacology experiment, at present, many higher vocational colleges introduce teaching assistant. With strict selection and the management model learnt from student associations, students in the group of teaching assistant are responsible for the arrangement of experiment process and assist teachers to arrange daily work. The setting of student teaching assistant is conductive to the cultivation of students' ability of coordination and cooperation and the training of their own practical capability. With the participation of teaching assistant, teachers can have more time to focus on experiment research and academic difficult points so as to provide better guidance in pharmacology experiment.

\section{New Path for Student-oriented Teaching Model of Pharmacology Experiment in Higher Vocational Colleges}

\subsection{To fully mobilize the enthusiasm and initiative of students for pharmacology experiment}

Pharmacology experiment is full with the fun of exploration, so teachers can adopt diversified teaching methods to improve students' enthusiasm for experiment. Take the poisoning and detoxicating of magnesium sulfate as an example to explore the method of teachers guiding students to actively participate in experiment. Assignment book is shown in Table 1.

From assignment book of experiment in Table 1, teachers shall propose thinking questions before the experiment and encourage students to find out answers in experiment, not simply finishing content in teaching material.

\subsection{To increase the proportion of design-oriented experiment}

Different from general experiment, design-oriented experiment requires students to select topic independently and design experimental scheme and procedures independently according to their knowledge learnt and problem to be explored. It examines the thinking ability, ability of experiment planning and the ability to comprehensively apply knowledge, with great openness, so as to provide more space for students to choose free and exert, which can inspire students' enthusiasm and initiative for pharmacology experiment. In addition ${ }^{[4]}$, in pharmacology experiment, students are generally divided into groups to refer to document and conduct experiment, which can train students' independent thinking and the ability of cooperation to meet student-oriented teaching of pharmacology experiment in higher vocational colleges. 
Table 1 Assignment Book of Pharmacology Experiment

\begin{tabular}{|c|c|c|c|c|c|c|}
\hline \multicolumn{3}{|c|}{ Course Name: Pharmacology } & \multicolumn{4}{|c|}{$\begin{array}{l}\text { Experimental Program: the poisoning } \\
\text { detoxicating of magnesium sulfate }\end{array}$} \\
\hline \multicolumn{2}{|c|}{ Training Class: } & \multicolumn{2}{|c|}{ Training Time: } & \multicolumn{3}{|c|}{ Training Place: } \\
\hline Student No. & 40 & $\begin{array}{c}\text { The Number } \\
\text { of Groups }\end{array}$ & 10 & \multicolumn{2}{|c|}{ Group Members } & 4 \\
\hline $\begin{array}{l}\text { Experimental } \\
\text { Objectives }\end{array}$ & \multicolumn{6}{|c|}{$\begin{array}{l}\text { 【Competence Objective】 To grasp capture method of rabbit and ear-rim intravenous } \\
\text { injection method. } \\
\text { 【Knowledge Objective】 To observe the poisoning symptom of experimented animal. } \\
\text { 【Quality Objective】 To foster the ability of finding out and solving problems. }\end{array}$} \\
\hline \multirow{4}{*}{$\begin{array}{l}\text { Experimental } \\
\text { Materials } \\
\text { and } \\
\text { Equipment }\end{array}$} & Name & Specification & Number & Name & Specification & Number \\
\hline & Infant Scale & & 10 & Rabbit & $2-5 \mathrm{Kg}$ & 10 \\
\hline & Injector & $5 \mathrm{ml}$ & 40 & $\begin{array}{l}\text { magnesium } \\
\text { sulfate } \\
\text { solution }\end{array}$ & $10 \%$ & 20 \\
\hline & Injector & $10 \mathrm{ml}$ & 40 & $\begin{array}{l}\text { calcium } \\
\text { chloride } \\
\text { solution }\end{array}$ & $5 \%$ & 20 \\
\hline $\begin{array}{l}\text { Experimental } \\
\text { Key Points }\end{array}$ & \multicolumn{6}{|c|}{$\begin{array}{l}\text { 1.To observe acute poisoning symptom of magnesium sulfate; } \\
\text { 2. Detoxicating feature of calcium chloride. }\end{array}$} \\
\hline $\begin{array}{l}\text { Experimental } \\
\text { Difficulties }\end{array}$ & \multicolumn{6}{|c|}{$\begin{array}{l}\text { 1.Capture and fix rabbit correctly; } \\
\text { 2. Intravenously inject medicine to ear-rim of rabbit. }\end{array}$} \\
\hline \multirow[b]{2}{*}{$\begin{array}{l}\text { Training } \\
\text { Conclusion }\end{array}$} & \multicolumn{6}{|c|}{ Filled by students } \\
\hline & \multicolumn{6}{|c|}{ Filled by teachers } \\
\hline \multicolumn{7}{|l|}{$\begin{array}{l}\text { Experiment } \\
\text { Notes }\end{array}$} \\
\hline $\begin{array}{l}\text { Thinking } \\
\text { Questions }\end{array}$ & $\begin{array}{l}\text { 1. What are } \\
\text { neuromuscul } \\
\text { 2. What ar } \\
\text { neuromuscul } \\
\text { 3. What are n }\end{array}$ & $\begin{array}{l}\text { echanism and } \mathrm{i} \\
\text { junction? } \\
\text { the influence } \\
\text { system? } \\
\text { ain poisoning sy }\end{array}$ & $\begin{array}{l}\text { ifluencing } \\
\text { and actic } \\
\text { nptoms of }\end{array}$ & $\begin{array}{l}\text { ictors of exci } \\
\text { mechanism } \\
\text { agnesium sul } \\
\end{array}$ & $\begin{array}{l}\text { tion-contractior } \\
\text { of magnesium } \\
\text { te? }\end{array}$ & $\begin{array}{l}\text { coupling in } \\
\text { sulfate on }\end{array}$ \\
\hline
\end{tabular}

\subsection{To create the opportunity for students to participate in experiment}

The prerequisite for the training of analyzing and practical ability in pharmacology experiment is that there is the opportunity to be involved in experiment. Some content of the course can be taught by teachers in classroom, and also can be further explored in laboratory by students. Therefore, teachers shall encourage students to participate in experiment by themselves, not accepting passively theoretical knowledge. In the experiment, it is possible for students to find out problems more rapidly and directly and generate motivation and interest in solving problems. At the same time, teachers need to encourage students to grasp the opportunity to participate in experiment, think more in experiment and conduct in-depth exploration in pharmacology experiment based their 
theoretical knowledge.

\subsection{To reasonably arrange teaching plan of experiment}

Student-oriented pharmacology experiment focuses on the development of students' thinking ability, therefore, before experiment, course teachers of pharmacology experiment shall formulate reasonable teaching plan targetedly ${ }^{[5]}$. The purpose of pharmacology experiment is to verify relevant theory of pharmacology and answer questions proposed by students in theoretical learning, which helps students to find out and solve new problems to further study theoretical knowledge. In formulating teaching plan of experiment, teachers shall pay attention to teach pharmacology experiment and theoretical knowledge at the same time, in this way, students' operational ability can be developed and theoretical knowledge can be consolidated.

\subsection{To develop rigorous and pragmatic learning attitude}

Pharmacology experiment requires students to conduct experiments with rigorous attitude. However, some students behave undisciplined with a learn-for-test attitude in experiment, fostering bad behaviors, which is disadvantageous in the teaching and future job of students. Pharmacology experiment is extremely rigorous, so students are required to speculate and query boldly, verify and practice carefully. In this way, teachers can guide students to implement experiment better and students also make progress in rigorous and pragmatic attitude.

\section{Conclusion}

The student-oriented model of pharmacology experiment in higher vocational colleges is beneficial for inspiring students' enthusiasm for experiment, developing rigorous and pragmatic learning attitude and implementing teaching of course teachers. It focuses on the cultivation of students' comprehensive ability, especially practical and thinking ability, to help the self-development of students. However, there are some problems in current pharmacology experiment, which requires further guidance of professional experiment teachers and cooperation of students. In conclusion, long-term exploration is necessary for student-oriented teaching model of experiment in higher vocational colleges to overcome more difficulties. In the process, teachers and students can make progress together.

\section{Acknowledgement}

Fund Program: University Science and Technology Program of Shandong Province (Project No. J18RB177)

Project name: Exploration and practice of effective ways and operation system of emergency rescue training

\section{References}

[1] Lu Xin. Student-oriented Concept to Improve the Quality of Pharmacology Experiment [J]. Journal of Henan Medical College for Staff and Workers, 2012, 24 (4): 549-550.

[2] Li Guangti, Hou Jialin, Zhang Yamin. Student-centered, Exploration and Practice in Improvement the Quality of Experimental Teaching [J]. Laboratory Science, 2012, 15 (4): 13-16.

[3] Xiao Li, Liu Maojun, Cao Lihua. Establishing a Student Teaching Assistant System to Increase Quality of Experimental Teachings [J] College Physics, 2008, 8 (8): 45-47.

[4] Lu Liqiong. The Analysis of American Graduate's Teaching Assistant System and the Suggestions [J]. Fudan Education Forum, 2005, 3 (1): 62-65.

[5] Guo Xiumin, Yang Rong, Wang Chun. On the Role of Students Acting as Teaching Assistants in Higher Educational Institutions [J]. Journal of Agricultural University of Hebei (Agriculture and Forestry Education Edition), 2004, 6 (2): 18-19. 